\title{
Girls' Mission Schools by the Canadian Woman's Missionary Society in Szechwan (Sichuan), 1894-1952
}

\author{
Yunjun Fang ${ }^{1, a}$ \\ ${ }^{1}$ Institute of Taoism and Religious Cultures, Sichuan University, Chengdu, Sichuan Province, China \\ a2572458883@qq.com
}

Keywords: Woman's Missionary Society; Mission schools for girls; Christianity; Modernizing China

\begin{abstract}
The Woman's Missionary Society of Canadian Methodist Church (the United Church of Canada since 1925) started its educational work in Szechwan (Sichuan) from the very beginning of its mission work, setting up schools for girls and young women. The work in the first period was slow in progress and experimental in nature because of the distrust and suspicion from the native people. Mission education for girls received a boost in the second period, with boarding schools and day schools founded in all 9 stations and a complete educational system established leading from kindergartens up to a women's college at West China Union University. After China gradually achieved autonomy in education and required mission schools to get registered in 1920s, mission education for girls in Sichuan entered its third period, shifting its focus from primary schools to the training of Christian leaders among women. The WMS's mission schools in Sichuan functioned primarily as a media to spread Christianity, attract converts among native females (school girls and their mothers), and eventually to Christianize Chinese homes and even China. The single women missionaries kept to their Victorian values and aimed mainly to prepare their pupils for their place at home as partners to their future husbands and mothers to the next generation. But mission schools did offer girls an opportunity to learn about a different style of life and enabled them to look at their own social and economic positions in the late $19^{\text {th }}$ and the first half of the $20^{\text {th }}$ China. Mission schools for girls encouraged a measure of individualism and a spirit of scientific inquiry by providing some science courses. The girls and young women, looking up to their missionary teachers as role models, began to thinking of creating a career in public social life, leading an independent life for themselves. In this sense, WMS mission schools for girls contributed to helping modernize Sichuan, or even China.
\end{abstract}

\section{Introduction}

The Woman's Missionary Society (WMS) of the Methodist Church of Canada started its West China work in 1892 by sending out its first missionary, Miss Amalia M. Brown, to Szechwan (Sichuan), China. During the long and dangerous journey to Chengtu (Chengdu), the capital of Sichuan, however, Miss Brown got married to Mr. David W. Stevenson, one of the first missionaries appointed by the General Board of the Canadian Methodist Church and travelling together to Sichuan. She thus quit from WMS. In 1892, Miss Sara C. Brackbill and Dr. Retta Gifford were appointed by WMS and they arrived in Chengdu in the spring of 1894, and this was often considered the real start of the WMS West Mission. The number of WMS missionaries grew slowly but steadily. In 1897, WMS appointed 4 missionaries. In 1900, there were 6 missionaries in Sichuan and in 1915 the number jumped to 25. In 1925 when a union between the Methodist, Congregationalist and two thirds of the Presbyterian churches in Canada was formed to create the United Church of Canada, there were 30 WMS missionaries active in duty in nine stations in West China. The highest number reached in 1926, totaling thirty-six. Between 1892 to 1953, just before the complete evacuation of Canadian missionaries out of China, WMS sent a total of 110 missionaries to China. The WMS Mission was engaged in evangelistic, medical and educational work. This paper will focus on the the educational work started or operated by the WMS missionaries in Sichuan. 


\section{WMS Mission Schools in Sichuan, West China}

The education of girls and women had been a part of the Canadian Protestant missionary enterprise in West China from the very beginning. Mission schools for girls were set up soon after opportunities were made available. Establishing the first girls' school in Chengdu in 1895, Miss Sara C. Brackbill aimed to turn it into a boarding school for girls. In 1895, this school enrolled 20 day school girls, and in 1898 it had 14 boarding students. A second day school was opened in the same year, enrolling 43 girl students. With the expansion of missionary work in West China, WMS missionaries started boarding schools and day schools in nine stations in Sichuan. During the years a complete system of Christian education was built up, leading from the Lower Primary to the High School, linking to the Union Normal School and then the Union University. In 1925, WMS had two boarding high schools, one in Chengtu and one in Tzeliutsing (now Zigong City), with 106 students enrolled. The Mission also had one boarding primary school in each station with a total of 487 students and 45 day primary schools in all nine stations, enrolling 2,351 young girls. In the same year, the Mission had 5 kindergartens in West China, taking in 164 small kids. The Union Normal School graduated 11 students in 1925 and the West China Union University accepted 8 women students in 1924, starting university education for young women in Sichuan.

Mission schools for girls established by WMS experienced three periods or stages. In early years before 1908, the missionaries had much difficulty gaining the local people's trust and confidence. With suspicion and distrust toward foreign missionaries, it was quite difficult for mission schools to get girls enrolled. In 1896 only twenty little girls were gathered into a small school in Chengtu and the next year four girls were taken in as boarding students.

During this first stage, the missionaries often attracted girls from poor families to come to school by providing free education and food. To ensure the continuation of the girls' education, missionaries required the parents of the girls to sign a contract with the school, promising not to disrupt the girls' education; otherwise, the parents had to repay the money used to support the girls. The subjects taught at school were quite limited and Christianity-centered as "half of the time was devoted to Christian books and the Catechism, S.S. Lessons, Life of Christ, and San-Tsi-King (an epitome of the Scripture)".[1] The classrooms and dormitories were often temporarily converted Chinese-style houses. The early annual reports of WMS would repeat news of school girls having contracted tuberculosis or news of deaths from this or that fatal disease.

In this difficult situation, mission schools by WMS still grew as confidence in foreign missionaries came slowly but steadily. In 1900 this girls' school in Chengtu had seventeen boarding students. Things began to improve even better after 1900, as people began to earnestly desire an education for girls. Work on the permanent school houses were begun in 1906 and it was to become the largest girls' mission school west of Chungking (Chongqing) to hold the then thirty-one boarding pupils. More subjects were taken up, including English and music. The senior pupils were trained to teach the younger ones. Educational work began to spread to other stations outside Chengtu. But the mission schools before 1907 were experimental and experienced trying years.

The second stage was from 1908 to 1927 , characterized by the rapid expansion of Christian education in West China. A boarding school was built and opened in each of the nine stations in West China. Day schools mushroomed in all stations, and in 1926 there were 52 WMS primary day schools. More subjects were taught at school. The year 1908 reported that girls in Chengdu Mission school were under a new course of study, having a fuller curriculum than children in similar grades in then Canada. Science courses for primary schools, besides all the regular studies, included geology, zoology, physiography, physics and botany. The pupils were also expected to be as well up in Chinese literature and history. Besides, the girls had from three to six hours a week direct Bible study, not including prayers and prayer-meetings. They also had a half hour singing lesson every day.[2]

Things were a bit different in middle schools or high schools. A small proportion of primary school graduates went on to high schools, from where the great majority of girls went directly into home-making, teaching, or some form of social and religious service. Almost all Chinese girls became home-makers, either immediately after leaving school or a few years later. The WMS high schools for girls in Chengdu and Kiating (Jiading, now Leshan City) therefore aimed to prepare their 
students to be good wives and mothers, and to make happy homes. Besides the regular subjects offered as in other schools, household science was a subject of fundamental value. The study of balanced diets, the care and discipline of children, first aid, hygiene, sanitation, and the treatment of illnesses were included in the curricula. A simple model home in which a few girls lived for a time, assuming full responsibility for everything in connection with it, was proved an important addition to the classroom study of home-making subjects. The partial responsibility of the older girls for little girls was a useful training in the care of children.

During this period, mission schools began to raise requirements for enrollment and to charge at least part of the fees on girls' education. In 1908 the Chengdu boarding school spent 800 Mexican dollars supporting students. This sum dropped to 200 dollars in 1909. The girls' boarding school in Chengdu, for instance, reported to have a larger number of paying pupils in 1913 and the support of students gradually stopped in future years. Support of students were common when starting mission schools in new stations, but still parents were asked to pay something to share the responsibility of their daughter's education. The mission school in Junghsien (Rongxian) reported in 1912 to hold thirty-two pupils' contracts, looking to the parents for the child's supply of clothing, books (the native books), paper, pens, and ink, extracting the promise that in arranging for their daughter's marriage the parents should confer with the missionary-in-charge, and that in default of keeping the girl in school till the expiration of the contracts, the parents should meet the financial obligation of the agreement up to the time of its close. In return for this, the pupil was to be nourished in body, mind and spirit. In the 1909-1913 Quadrennial Report, it was declared that "in addition to the outlay by the Society it is worthy of note that $\$ 28,409.80$ have been received in Japan from students' fees, etc. China is also beginning to recognize this phase of obligation".

Most students were still from poor families, but the year 1908 reported that one pupil was the daughter of an official. Considering the distrust or even hostility of the gentry class toward foreigners, this was an encouraging sign. In 1923 WMS Chungking (Chongqing) boarding school for girls received applications for admission from many classes, "a preponderance from well-to-do homes".

Conditions in the Mission schools were greatly improved. In 1908, the large building and the gymnasium for the boarding school in Chengtu had been completed. Permanent school buildings in other stations were also planned or under construction, which would "help to impart the spirit of study more along foreign lines".[3] In the same year, WMS mission schools pupils took part in the first public examination given by the Christian Education Union of West China (CEUWC), becoming a part of the uniform Christian educational endeavors in West China (covering three provinces: Sichuan, Yunnan and Guizhou).

With the rapid growth of primary education, one of the most urgent needs in China was then for well trained teachers for elementary schools, Christian, government, and private. Graduates of middle schools, who had received some normal training, would do excellent work in primary (and also lower middle) schools. So through the years the aim of the girls' boarding school in each station was to prepare teachers for day schools. In view of the great demand for women teachers, the large proportion of middle school or high school graduates who would enter the teaching profession, and the fact that all mothers needed at least some knowledge of teaching to train their children, Chengtu Union Normal School for Young Women was founded in 1915, being the first institution of its kind in West China and a giant leap in the training of women teachers. Fourteen students were admitted in the first year and the general principle was that a girl assisted through the Normal School by WMS Mission, should return service by teaching for two years in WMS schools. Courses offered included Principles of Teaching and General Method, School Management, Psychology, Calisthenics, Chinese Literature and Essay-writing, English (optional), a course in Bible study and one in Studies in Christian Service, and Special Method in all the subjects of the students' practice teaching. The students would do, under supervision of missionaries, regular practice teaching in the Junior Primary day school in such subjects as Chinese Literature, Arithmetic, Geography, Hand-work, Physiology, Ethical readers, and Calisthenics.

At the same time, an increasing number of middle school or high school girls were going on to 
further study in college, normal school, medical school, nurses' training school, Bible training school, or training school for physical directors. The WMS West China Mission began to look forward to the higher education for their girls and requested women missionaries to be sent out for special work in connection with universities and teachers training schools. In 1925, WMS mission attempted co-education in the West China Union University and the first batch of eight women students started their college education.

The third stage of WMS Christian education in Sichuan started in 1927. The rapid transformation of Chinese society increased the desire of the authorities to ensure that they had complete control over education. Since 1920s, China began to achieve some autonomy in education, requiring mission schools to get registered with the Chinese authorities. Registration involved two major issues -- the controlling body and the administrative staffs must be Chinese and there must be no religious instruction in school hours, or indeed on the school premises at any hour. Financial difficulties were a continuing problem hassling Mission schools through 1920s, which was compounded by the need for these schools to meet government regulations, but at the same time satisfy the desire of the Mission to maintain the schools as Christian institutions.

Government regulation of education naturally raised the important question for missionary societies of whether the expense of maintaining mission schools was worthwhile when these schools could not provide Christian education within their curricula. Registration required finances and with the depression of economy in Canada, some WMS schools in Sichuan were later closed because of reduced support from Home Board back in Canada. Even for those schools which intended to get registered, there existed the real need to give up the missionary domination in school affairs. The missionaries would have to devolute the control and management of mission schools to their Chinese colleagues.

Since 1930s, with the Chinese government improving its educational programme, the need for mission and church schools for secular education was not as urgent as years before. Primary education was almost entirely in the hands of the Government. Schools were springing up in all the little towns and villages. During the most prosperous years of the WMS West China Mission, it had twenty-one Primary schools on the Tzeliutsing district only. In 1944, this number was reduced to only two Full Primary schools and one Junior Primary school in all West China Mission. Mission schools became almost self-supporting.

The new situation demanded a careful study of the WMS Mission's whole educational programme and a reconsideration and revaluation of its educational institutions. The 1943 annual report included a detailed analysis of the challenges WMS encountered in the changing conditions, mainly three: the challenge toward the development of Chinese leadership, the challenge to ht missionary herself and the challenge to the students. The report further arrived at the conclusion that "many changes were taking place in the role of the missionary in the school, financial problems, removal of schools, destruction of plant, etc. that .... (the mission's) educational work must tend more and more to be developed in educational centers rather than in small scattered units". [4] So closing some of the Primary schools became the first move to shift the focus of its educational work. It was also decided that the Mission should not attempt to run so many High Schools but that it should concentrate on three only, giving them and the Child Study centre its utmost cooperation and help. Of course, Mission schools still attempted to offer a Christian alternative to the state educational system and to Chinese private schools, but in a different way, to concentrate on the development of those educational institutions aimed to train Christian leaders in China, such as teachers' training schools, theological colleges and university education.

The Union Theological College, a cooperated institution established in 1937, enrolled twenty-two students in the first year, including four women from WMS Mission. Growing fast and playing an ever-increasing part in the training of leaders for an indigenous Christian Church, this college had seventy-two students, including twenty-one women in the fall of 1941, when the building of its permanent plant had been just completed. In 1947, the eleventh year of the Union Theological College, 36 women graduates, including both college and junior grade, had gone out from the college. This same year, Helen Pen, one of the 1945 graduates, was the first woman to be ordained in West 
China.

The Women's College of West China Union University, established in 1924 with the first graduating class of five in 1929, boasted of remarkable development through the years. In 1947, West China Union University had a total of 2,081 students, of whom 789 were women. 324 women were in Arts, 284 in Science, 134 in Medicine, and 47 in Dentistry. The class of 1948 brought a total number of women graduates of this University up to 695, 301 went out from the College of Arts, 209 from the various departments of the College of Science, 100 went out as Doctors of Medicine, 36 as Dentists, 16 received diplomas from a special agriculture course, and 3 from the Hospital technicians courses. The women graduates were filling responsible positions in hospitals, both church-operated and government operated, in laboratories, in private medical and dental practices, on the staffs of the Mission Middle schools and colleges and in government schools, in business firms and banks, in churches, and as homemakers bringing new ideals and new character to the home life of modern China.

Another department the Mission devoted to was child study centers, the largest one being the Child Study Center in Chengtu. In 1944, the Chengtu Center had in its kindergartens and nurseries 200 children. Through its playground work for underprivileged the Center cooperated with the university in a project which affects 30 children and their homes, and gave practical training in this field to six university students. Through its cooperation with the government, the Centre trained kindergarten teachers, reaching out into the community and helping to further projects which had at heart the welfare of small children.

So in this third stage, WMS schools mainly focused on the effort to train Christian leaders in China, to spread its influence in communities.

\section{Influence of WMS Mission Schools on China's Social Life}

WMS schools for girls, like other missionary work, became an agency or a channel to transmit the missionaries' domestic ideals to the Chinese girls and women. The Canadian women missionaries engaged in missionary work in Sichuan were exposed to experience and fulfillment unavailable to these women in Victorian Canada. But they could not easily discard the patriarchal and imperial notions they believed in. In the girls' schools they founded they tried to impart their values to the Chinese girls. That's why in early years, although the WMS girls' schools on the whole "followed the WCCEU curriculum, academic learning was not the goal, believed "that faith in God and loving service for others are of more value than knowledge gained from books". [5] Girls in mission schools helped with all the school house work, preparing meals, washing dishes, washing floors, making beds and all their own clothing. There would be a woman who would come regularly to teach the girls sewing and under whose supervision, all except the very small ones had to learn to make their own dresses, stockings and shoes. The later Home Science Programme aimed to teach the pupils Chinese customs, etiquette, cooking, care of children, household economy and so on, all of which was to train girls for their future family as helpers to their husbands. In a sense, the missionaries modeled social roles that were only superficially different from those traditionally accorded Chinese women in a patriarchal and male-dominated society. A detailed examination of the missionaries' activities would find out they did not challenged prevailing social norms in China, thereby contributing to significant social change for Chinese women.

The mandate in the school work was to Christianize Chinese women and the missionaries sincerely believed that real Christian homes were the greatest asset a country could have. Mission schools were an effective way to attract converts. Missionaries considered that the most fruitful way to make converts was to teach the young girls, as they were not yet fully educated in Chinese customs and habits, while also gaining access to their homes and therefore the possibility of converting their parents as well. Under the influence of Christian teaching and Bible study, not a small proportion of the pupils were baptized. Through the mother' meetings, missionaries came into contact with mothers. Mothers' meetings at mission schools was effective in winning mothers' confidence and trust and helped in promoting evangelistic work.

Despite the fact that educational work was just a means to evangelize Chinese women and girls 
and attract converts, it is undeniable that mission schools brought some positive influence on the girls and women in China.

In terms of curriculum, mission school for girls put an emphasis on mathematics, physical and biological sciences, medical education and laboratory work, aiming to introduce the spirit of scientific inquiry. Besides academic subjects, the physical and moral development of their pupil were considered as crucial. Mission schools for girls stressed physical exercise (including ball games and drilling), recreation, personal hygiene. They did not underestimate the importance of character development and the individual personality of girls and young women, though moral cultivation for them mainly meant inculcating general Christian values. For WMS missionaries, one purpose of education was the inculcation of good manners and proper Christian conduct consistent with their own Victorian values. But the teachers did make efforts to encourage students to be actively involved in community activities and social welfare projects. The girls organized many Chinese Girls in Training (CGIT) groups to teach the poor children to read in the neighborhood, or raise money to help people in war-torn or disaster-stricken areas. This emphasis on physical exercise and moral development coincided with the New Life Movement advocated in China in 1930s.

Through women missionaries' work, Chinese girls and women obtained necessary information about Western women's lives in their own countries, which encouraged them to look at their own social and economic positions, and to get an education. They began to question the accepted patriarchal values, to defy the practice of foot-binding, arranged or forced marriage, to follow their teachers' example to become independent women supporting themselves. Many Chinese women for the first time were able to envision themselves participating in the social and economic life of the nation. They came to accept the notion that girls, like boys, should have the opportunity to be educated. After graduation, many Chinese women went on to establish a career, often in the field of education, nursing or evangelistic work. With well-paying jobs, they managed to gain some economic and personal independence. The 1936 report mentioned a Mrs. Li from Jiating who helped other women and children in Gin Ien (now Jingyan county in Sichuan). Mrs. Li was a grass-root Bible woman whose primary aim was to spread Christianity, but her work in literacy class and basic medical care was valuable to the local community. She also became a kind of independent women through her work to help others.

At a higher level, a class of professional women began to emerge. The 1937 report mentioned graduates from WMS Music Department who had "come to the place where they might be taken on as staff members". One Miss Dorothy Dai took charge of the music, both instrumental and vocal, of the Junior Middle School in Chengtu. One Miss Dehlia Song would become a member of the Fine Arts staff at the West Union University. These kind of examples abound. Miss Dju Shu Chwan, a 1932 graduate of the School of Nursing in Chengtu, was appointed principal of this school in 1937, after she finished her post-graduate study in Hankow and Peiping and came to work in Chengtu Hospital.[6] Miss Pearl Chiang became the principle of the Union Normal School in Chengtu and left for Canada to pursue her postgraduate study in 1937. After she came back upon the completion of her study, she again was the principal of the Normal School and later became an expert in preschool education with a nation-wide reputation. This class of professional women contributed to the modernization process of China. With their education and their training, they began to get outside of their home and earned a share in independence in social and economic life.

Under the influence of single women missionaries and with their newly-earned independence, Chinese girls and women changed their views in family life and marriage. They began to fight against the then common practice of arranged or forced marriages by their parents. Marriage was no longer the only choice for young women and they could choose a husband of their love.

Of course the direct impact of the WMS mission schools and of women missionaries was limited to a relatively small group of girls and young women who had personal contact with the missionaries. But the WMS missionaries saw education as the key to the improvement of Chinese women's social and economic status. 


\section{Conclusion}

The educational work by WMS missionaries was primarily aimed to spread Christianity among the Chinese girls and women, thus eventually Christianizing Chinese families. The missionaries started mission schools for girls with the belief that education as intellectual enlightenment would lead to conversion to Christianity and the elimination of social evils, such as foot binding, female infanticide, and various forms of injustice or slavery imposed on girls and women in China. The opening up of the minds of Chinese females, who would be future partners of the male converts and mothers of the next generation, was considered crucial to the progress of the Gospel.

In the early twentieth century, mission schools provided a separate and unique educational system parallel to the national system of the Chinese government. After the registration and the shift of administrative power from missionaries to the Chinese, mission schools began to lose appeal and privileges in the eyes of the missionaries. Financial difficulties further reduced the enthusiasm of keeping up mission schools. The WMS Mission began to swift its focus from primary schools to teachers training programme and university education. They hoped to provide secular education of a higher level in a Christian atmosphere. This effort helped to create a class of elite girls and young women who entered profession careers, initially teaching, then medicine, nursing and church work.

Although what Chinese girls and young women learned from their missionary teachers could not necessarily revolutionise their lives, or empower them to change the Chinese society, it nevertheless exposed them to different life styles, to role models active outside their homes, and to the possibility of creating a new world for themselves. Mission school education facilitated social mobility for girls and women, offering them better marital prospects, cultivation of ambition, and preparation for leadership in public life. Through Christian education, mission schools for girls and women contributed to the development of individualism and the emergence of a new, emancipated class of Chinese women. In this sense, we cannot deny that the mission school for girls made its measure of contribution to the modernization of China.

\section{References}

[1] Sixteenth Annual Report of the Woman's Missionary Society of the Methodist Church, Canada, 1896-1897 (Toronto: Methodist Book and Publishing House, 1897), lv.

[2] Twenty-Seventh Annual Report of the Woman's Missionary Society of the Methodist Church, Canada, 1907-1908 (Toronto: Methodist Book and Publishing House, 1908), lix.

[3] Ibid, lviii.

[4] Eighteenth Annual Report of the Woman's Missionary Society of the United Church of Canada, 1942-1943, (Toronto: the United Church Publishing House, 1943), 165.

[5] Alvyn Austin, Canadian Missionaries, Indigenous Peoples: Representing Religion at Home and Abroad (Toronto: University of Toronto Press, 2005), 123.

[6] Twelfth Annual Report of the Woman's Missionary Society of the United Church of Canada, 1936-1937 (Toronto: the United Church Publishing House, 1948), 259-263. 